\title{
Review of the genus Cbrysolina Motschulsky, 1860 (Coleoptera: Chrysomelidae) from Nepal Himalaya with description of a new species
}

\author{
O6зор рода Chrysolina Motschulsky, 1860 (Coleoptera: \\ Chrysomelidae) из Непальских Гималаев с описанием нового вида
}

\author{
Yu.E. Mikhailov \\ Ю.Е. Михайлов
}

Ural Federal Yeltzin University, Mira str. 19, Yekaterinburg 620002, Russia. E-mail: yum_66@mail.ru.
Ural State Forest Engineering University, Sibirsky trakt 37, Yekaterinburg 620100, Russia.
Уральский федеральный университет, ул. Мира 19, Екатеринбург 620002, Россия.
Уральский государственный лесотехнический университет, Сибирский тракт 37, Екатеринбург 620100, Россия.

KEY WORDS: Chrysolina, Chrysomelidae, Nepal, Himalaya, review, new species.

КЛЮЧЕВЫЕ СЛОВА: Chrysolina, Chrysomelidae, Непал, Гималаи, обзор, новый вид.

ABSTRACT. 11 species and subspecies of Chrysolina hitherto known from Nepal are reviewed. From them only 4 species and 1 subspecies not attributed to exact subgenus can be treated as Himalayan typical alpine species. One more new species Chrysolina romandudkoi Mikhailov sp.n. is described from alpine zone of Eastern Nepal. Short aedeagus with broad anchor-shaped apex distinguishes it from all known Nepalese Chrysolina. Elytra with regular rows of punctures place the new species closer to $C h$. dhaulagirica and Ch. hartmanni, but from both species having margins of elytra red fulvous it differs in uniformly dark bronze colour and lateral callus of pronotum not separated from disc. From Ch. nagaja and Ch. daccordii having uniformly bronze body and similar habitus it differs by regular punctures on elytra. The key to high mountain Chrysolina from Nepal Himalaya is provided.

РЕЗЮМЕ. Дан обзор 11 видов и подвидов Chrysolina, известных на данный момент из Непала. Из них только 4 вида и 1 подвид, не отнесённые к конкретным подродам, могут рассматриваться как типичные гималайские высокогорные виды. Ещё один новый вид Chrysolina romandudkoi Mikhailov sp.n. описан из альпийской зоны Восточного Непала. Короткий эдеагус с широкой якоревидной вершиной отличает его от всех известных непальских Chrysolina. Надкрылья с правильными рядами пунктировки сближают новый вид с $C h$. dhaulagirica и Ch. hartmanni, но от обоих видов, имеющих краснорыжие края надкрылий, он отличается одноцветно бронзовой окраской и не отделёнными от диска боковыми валиками переднеспинки. От Ch. nagaja и Ch. daccordii, имеющих одноцветно бронзовую окраску и сходный внешний вид, он отличается упорядоченной пунктировкой. Дан ключ для определения высокогорных видов Chrysolina из Непальских Гималаев.

\section{Introduction}

The Central or the Nepal Himalaya is one of the four parts of the Himalayas about $800 \mathrm{~km}$ long between the rivers Kali in the west and Teesta in the east (the rest are the Northwest or the Punjab Himalaya, Kumaon or the Western Himalaya and the Eastern or the Assam Himalaya). Several well known peaks higher than $8000 \mathrm{~m}$ a.s.l. like Mt. Everest, KinchinJunga, Makalu, Dhaulagiri, Annapurna, ets. are situated in this division [Mani, 1968].

The earliest collections of high altitude insects from the Himalaya were made from the Northwest part, especially by the Dutch and German Karakoram and Nanga Parbat expeditions in the first half of XX century and Mani's entomological expeditions later on. Consequently Mani [1968] in his well known overview of high altitude insects mentioned only few species of leaf beetles mainly from Punjab Himalaya. In Central Himalaya high altitude Coleoptera at that time were mainly collected by different Mt. Everest expeditions [Mani, 1968]. Although during the last 50 years the situation has changed due to intense studies by German, Swiss and Japanese expeditions to Nepal Himalaya, whose resuls on Chrysomelidae were summarized in several catalogues [Medvedev, Sprecher-Uebersax, 1999a; Kimoto, 2005; Sprecher-Uebersax, 2011]. In the most recent

How to cite this article: Mikhailov Yu.E. 2019. Review of the genus Chrysolina Motschulsky, 1860 (Coleoptera: Chrysomelidae) from Nepal Himalaya with description of a new species // Russian Entomol. J. Vol.28. No.1. P.58 63. doi: 10.15298/rusentj.28.1.08 
of them the total number of Nepalese leaf beetles was estimated as 1037 species that is still far from complete.

In May - June 2018 Russian entomologists Roman Dudko and Boris Kataev surveyed the remote highlands in Bhodjpur and Solukhumbu Districts of Eastern Nepal and I was lucky to study the material on Chrysomelidae collected by Roman Dudko. Among them I payed special attention to the species of Chrysomelinae, whose alpine faunas in Palaearctic are familiar for me. Although Nepalese fauna in general is typical Oriental one, the high mountain Chrysomelidae of the Himalayas have dominating groups closer to Palaearctic with $44 \%$ of Alticinae, $28 \%$ of Galerucinae and $24 \%$ of Chrysomelinae [Hartmann, Medvedev, 2003]. According to Sprecher-Uebersax [2011] with the corrections and additions from Ge et al. [2012] subfamily Chrysomelinae in Nepal includes 52 species and subspecies with 26 (or exactly half of them) endemic. The endemism of higher level is much less, with one genus Parambrostoma Chen, 1934 subendemic with Tibet and one subgenus Sclerophaedon (Tantraedon Daccordi et Medvedev, 2000) subendemic with India.

From the first glance it was not easy to attribute two of newly found species to exact genus. Both of them have anchor-shaped aedeagus (Figs 3-9) that is peculiar to the representatives of Parambrostoma. This genus is restricted mainly to the Nepal Himalaya in the zone of temperate forests below $3300 \mathrm{~m}$ a.s.l. but displays morphological characters of alpine species, such as the absence of hind wings and a shiny metallic surface [Ge et al., 2012]. Although the representatives of Parambrostoma have well-defined transverse depression at basal region of the elytra and peculiar multicoloured dorsal surface with purple or violaceous spots on head and green or purple markings on pronotum and elytra [Ge et al., 2012]. Taking into account uniform bronze colour, absence of transverse depression on elytra and other characters according to the key to the leaf beetle genera of Nepal [Medvedev, Sprecher-Uebersax, 2005] I attributed the new findings to the genus Chrysolina Motschulsky, 1860.

The material examined in this paper is housed in the following collections and depositories: ISEA - Institute for Systematics and Ecology of Animals, Siberian Branch of Russian Academy of Sciences (Novosibirsk); YMC — collection of Yuri Mikhailov (Yekaterinburg), ZIN - Zoological Institute of Russian Academy of Sciences (St.- Petersburg).

Review of the genus Chrysolina Motschulsky, 1860 in Nepal

11 species and subspecies of Chrysolina are hitherto known from Nepal [Sprecher-Uebersax, 2011]. According to the Palaearctic Catalogue [Kippenberg, 2010] three of them belong to the subgenus Pierryvettia Bechyné, 1950, three - to Diachalcoidea Bechyne, 1955, two - to Semenowia Weise, 1889, one - to Chalcoidea Motschulsky, 1860, one - to Litho- pteroides Strand, 1935, and one is not attributed to exact subgenus.

Pierryvettia species having well developed wings, elongate and moderately convex body with large punctures on elytra and pronotum are quite peculiar, all Nepalese representatives of this subgenus have larger distribution areas in Oriental region [Kimoto, 2005; Sprecher-Uebersax, 2011]. Ch. conglomerata Maulik, 1926 is known also from India, Ch. separata separata (Baly, 1860) (= aurata Suffrian, 1851) - from Bhutan, India, China, Myanmar, Thailand, Laos and Vietnam, Ch. inconstans (Wiedemann, 1823) - from India and Ceylon. Ch. bowringii (Baly, 1860) is not found in Nepal, but known from Bhutan, China, Vietnam. Pierryvettia species inhabit relatively low altitudes 1300 $1400 \mathrm{~m}$ [Medvedev, 1990], in the eastern part of the Himalaya these elevations belong to the subtropical zone, where numerous forest types are found [Halberg, 2017]. Ch. (Lithopteroides) exanthematica exanthematica (Wiedemann, 1821) inhabits the same lower altitudes. This species was described from Bengalia but now is known as multiregional species distributed from temperate zone (Eastern Kazakhstan, Altai, Sayans, Transbaical, Yakutia, Russian Far East, Mongolia, Eastern China and Korea) to subtropical and tropical zones (Pakistan, India, Nepal, Vietnam). Therefore the Nepalese representatives of Pierryvettia and Lithopteroides can be treated as the subtropical and not specialized mountainous faunistic elements.

Chrysolina vishnu (Hope, 1831) (= parvati Daccordi, 1982), the only representative of Chalcoidea, is a Himalayan species, known from Nepal, Bhutan and India on the altitudes from 400 to $2900 \mathrm{~m}$ a.s.1. [Daccordi, 1982] but mostly found at 1000-2000 m a.s.1. [Medvedev, 1990]. This species is connected with lower temperate zone.

The rest of Chrysolina species can be treated as Himalayan typical alpine species in the meaning that they have reduced wings and inhabit high mountain biotopes above treeline.

Two species, namely Ch. nagaja (Daccordi, 1982) and Ch. daccordii (L. Medvedev et Sprecher-Uebersax, 1999), were described in the separate genus Semenowia, which was subsequently included by Daccordi [1994] in the genus Chrysolina as a subgenus. Although these two species were later excluded from the subgenus Semenow$i a$ and placed in a separate species group not attributed to exact subgenus but close to Timarcholina Bechyne, 1950 from India and Sri Lanka [Bienkowski, 2013].

Ch. daccordii was recorded in Western Nepal at Annapurna and Manaslu Mts. at the elevations 3300$4200 \mathrm{~m}$ [Medvedev, Sprecher-Uebersax, 1999b]. Ch. nagaja has locus typicus in Pakistan (Jhica Gali) at the elevation of $2100 \mathrm{~m}$ a.s.l. [Daccordi, 1982], but the accuracy of this indication is questionable because of low altitude and situation outside the Punjab Himalaya. Later on Ch. nagaja was found in Eastern Nepal in Sankhuwasabha and Taplejung districts in pastures and alpine meadows at the elevations 4100-4500 m [Medvedev, 1992]. Here I indicate one more locality of Ch. nagaja from 


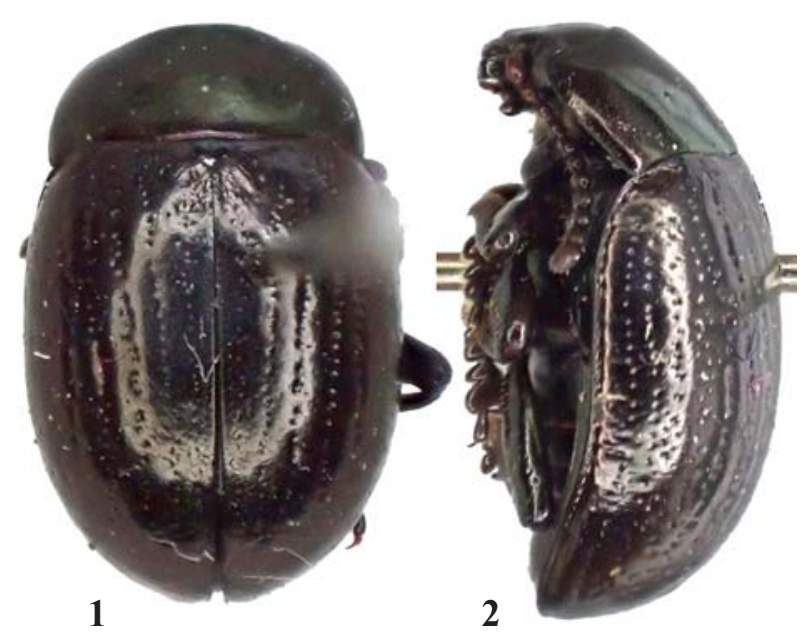

Figs 1-2. Chrysolina tangalaensis Kimoto, 2001, male, holotype, general dorsal and lateral view. Photo by Dr. Ako Tachi (Kyushu University, Fukuoka, Japan).

Рис. 1-2. Chrysolina tangalaensis Kimoto, 2001, самец, голотип, общий вид сверху и сбоку. Фото д-ра Ако Тачи (Университет Кюсю, Фукуока, Япония).

Eastern Nepal: Solukhumbu Distr., 1 km NE of Lamjura La Pass, Langgate Mt., 3700-4000 m, 27 $35.3^{\prime} \mathrm{N}, 86^{\circ} 30.2^{\prime}$ E, 2.06.2018, R.Yu. Dudko leg., $2 \sigma^{7} \sigma^{7}$ (YMC).

Ch. dhaulagirica dhaulagirica Medvedev, 1990, Ch. dhaulagirica arunensis Medvedev, 1992 and Ch. hartmanni Medvedev, 1999 found at the elevations 2800-4600 m. have regular rows of punctures and red fulvous marginal stripe on elytra [Medvedev, 1990, 1999]. These taxa were attributed by Kippenberg [2010] to the subgenus Diachalcoidea Bechyne, 1955. But I cannot support this point, because other species of this subgenus, namely Ch. aegyptiaca Olivier, 1807 and $C h$. sacarum Weise, 1890 both ecologically and morphologically differ from Nepalese ones that form a separate species group. Medvedev [1990] stressed the possible
Palaearctic roots of Ch. dhaulagirica and proposed to include it in the subgenus Pezocrosita Jacobson, 1901. Although it is Chrysolina tangalaensis Kimoto, 2001 that according to the photos of the types kindly provided from Kyushu University (Figs 1-2) stays closer to temperate subgenera Arctolina and Pezocrosita. This species collected at the elevations $4000-4600 \mathrm{~m}$ is still not very clear with aedeagus not illustrated, but it differs from other high altitude Nepalese Chrysolina having relatively large punctures in the rows of elytra, elevated interstriae and broad male tarsi.

After the review of all hitherto known species of Chrysolina from Nepal I describe one more species that proved to be new to science.

\section{Chrysolina romandudkoi Mikhailov sp. $\mathbf{n}$.} Figs 3-7, 19-21.

MATERIAL. Holotype, $\sigma^{7}$ with labels: 1) E Nepal, Bhodjpur Distr., $1,5 \mathrm{~km}$ NE Salpa pass, $\mathrm{h}=3350 \mathrm{~m}, 27^{\circ} 26.7^{\prime} \mathrm{N}, 86^{\circ} 56.1^{\prime} \mathrm{E}$, at night with torch, 21.05.2018, R. Dudko leg. 2) HOLOTYPUS, Chrysolina romandudkoi sp. n. Yu. Mikhailov design. 2018 [red] (ISEA). Paratypes: $3 \sigma^{\top} \sigma^{\top}, 2+\circ$, E Nepal, Bhodjpur Distr., $1 \mathrm{~km}$ E of Salpa Pass, 2800-2850 m, 27²5.6' N, 86 56.6' E, 20.05.2018, R. Dudko leg., $10 \sigma^{\top} \sigma^{\top}, 4 \circ \circ, 1,5 \mathrm{~km}$ NE Salpa pass, h=3350 m, $27^{\circ} 26.7^{\prime} \mathrm{N}, 86^{\circ} 56.1^{\prime} \mathrm{E}, 21.05 .2018$, R. Dudko leg., $2 \mathrm{O}^{\top} \mathrm{\sigma}^{\top}, 1$, ${ }^{\circ}, 2 \mathrm{~km}$ NE Salpa pass, $\mathrm{h}=3750-3800 \mathrm{~m}, 2^{\circ} 27.3^{\prime} \mathrm{N}, 86^{\circ} 56.4^{\prime} \mathrm{E}, 22.05 .2018$, R. Dudko leg., 10', 1 , $2.5 \mathrm{~km}$ NE of Salpa Pass, 3800-4150 m, $27^{\circ} 27.5^{\prime} \mathrm{N}, 86^{\circ} 56.4^{\prime} \mathrm{E}, 23.05 .2018$, R. Dudko leg., $3 \sigma^{\top} \sigma^{\top}, 3 \circ{ }^{\circ}$, Solukhumbu Distr., $0.5 \mathrm{~km} \mathrm{NW}$ of Salpa Pass, 3000-3100 m, $27^{\circ} 26.8^{\prime} \mathrm{N}, 8^{\circ} 55.2^{\prime} \mathrm{E}, 24.05 .2018$, R. Dudko leg. All the paratypes (30 specimens) with the red label: PARATYPUS, Chrysolina romandudkoi sp. n. Yu. Mikhailov design. 2018 (YMC, ISEA, ZIN).

DESCRIPTION (holotype). Body uniformly bronze, antennae and tarsi black with metallic luster, claws brown. Convex, obovate, slightly constricted laterally between pronotum and elytra; shining, pronotum distinctly shagreen, elytra smooth with thin wrinkles and microscopically punctulate.

Last maxillary palpomere narrow, oval, $1.5 \mathrm{x}$ as long as broad and 1.2-1.3x as long as previous palpomere and 1.0$1.1 \mathrm{x}$ broader than latter. Antenna inserted 1.9-2.1x closer to clypeus than to eye, with antennomeres 10 and 11 project beyond pronotal base. Antennomeres 6-11 weakly broad-
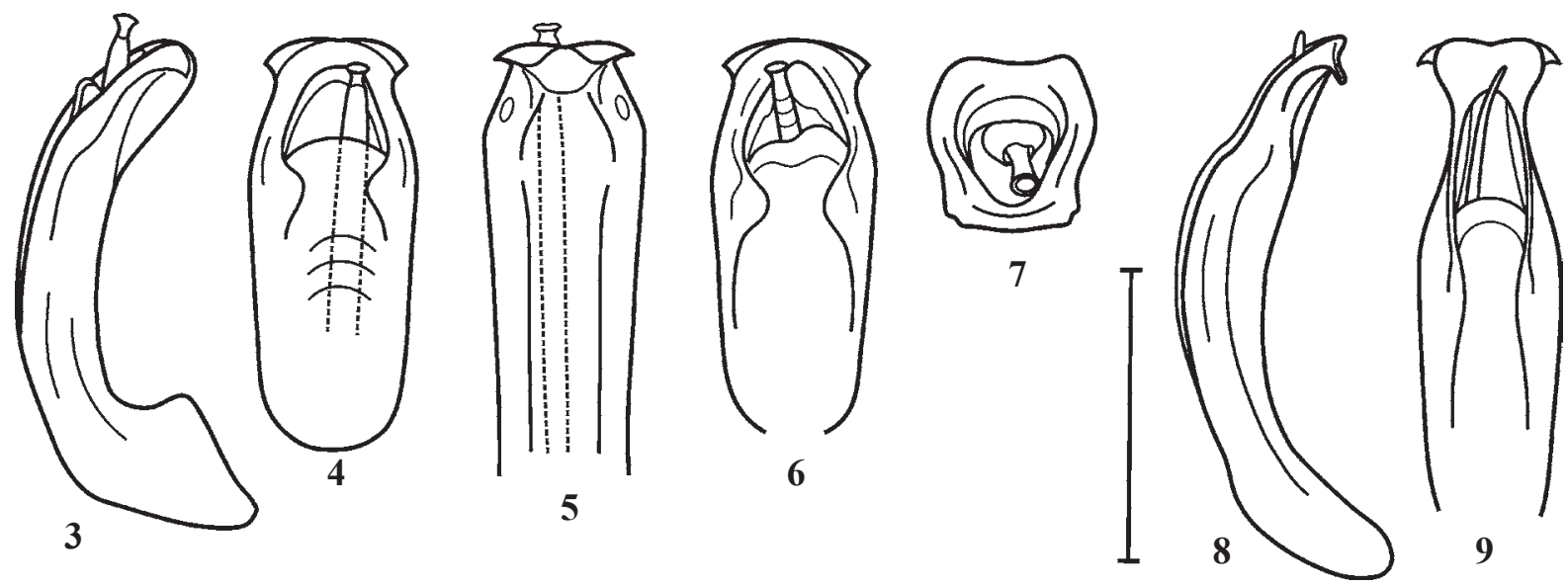

Figs 3-9. Chrysolina, aedeagus structure: 3-7 - Ch. romandudkoi sp.n.; 8-9 - Ch. nagaja (Daccordi, 1982) from Solukhumbu Distr., env. Lamjura La Pass; 3, 8 - lateral view, 4, 6, 9 - dorsal view (4 - holotype), 5 - ventral view, 7 — view of the apex and apical orifice along the main axis (paratype). Scale bar $-1 \mathrm{~mm}$.

Рис. 3-9. Chrysolina, строение эдеагуса: 3-7 - Ch. romandudkoi sp.n.; 8-9 - Ch. nagaja (Daccordi, 1982) из paйона Solukhumbu, окрестностей перевала Lamjura La; 3, 8 - сбоку, 4, 6, 9 - сверху (4 - голотип); 5 - снизу; 7 -вершина и апикальное отверстие вдоль продольной оси (паратип). Масштаб - 1мм. 
ened. Orbital lines broadly impressed above eye, not projecting along inner border or eye.

Pronotum $1.75 \mathrm{x}$ as broad as long, moderately convex, broadest before the middle of its length. Anterior angles moderately produced, basal angles sharp. Anterior side of pronotum entirely marginate, with setae. Both anterior and posterior setiferous pores present. Pronotum laterally weakly swollen along entire length, lateral calli weakly or not pronounced, lateral impressions obsolete, only in basal $1 / 4$ with punctures larger than those at disk. Punctures at pronotal disk moderately dense and fine, in addition several large punctures can be seen in posterior third. Hypomera of prothorax almost flat, weakly convex, smooth. Basal fold distinct. Intercoxal prosternal process broadened posteriorly. Anterolateral portions of prosternum flat, anteriorly marginate, with wide impression posteriorly. Metasternum entirely marginate anteriorly, with broad and convex callus between mid-coxae. Scutellum triangular, smooth, without punctures.

Elytra with very feeble humeral calli, with 9 slightly irregular rows of fine punctures and abbreviated scutellar row from 4-5 punctures. Rows except the $1^{\text {st }}$ one are slightly paired, $6^{\text {th }}$ row in the basal impression consists of large and deep punctures. Intervals flat, covered by sparse, obsolete wrinkles and very fine punctures. Epipleura inclined outside, visible along entire length in lateral view. Hind wings vestigial, narrow, slightly longer than metathorax.

Tarsi densely pubescent beneath, $3^{\text {rd }}$ segment of all tarsi moderately dilated. Tarsomere 4 without denticles beneath.

Pygidium with well pronounced impression along entire length. Last abdominal sternite evenly convex, broadly truncate and marginate apically in male and female.

Aedeagus tube-shaped, apically truncated, with lateral denticles; flagellum straight tubular, exposed (Figs 3-7). Length $6.2 \mathrm{~mm}$, width $4.2 \mathrm{~mm}$.

VARIABILITY of males. Rarely pronotum obsoletely shagreen and looks as smooth as elytra, punctures in elytral rows may slightly vary in size (Figs 19-20). Hypomera of prothorax sometimes with thin wrinkles along outside.
Length $6.0-7.0 \mathrm{~mm}$, width $4.0-5.0 \mathrm{~mm}$

Females. Antennomeres 6-11 weakly broadened, narrower than in males. Pronotum laterally weakly to moderately swollen along entire length, lateral calli weakly or not pronounced, lateral impressions obsolete or very smooth and pronounced only in basal 2/3 (Fig. 21). Last maxillary palpomere $1.6 \mathrm{x}$ as long as broad, $1.2 \mathrm{x}$ as long as previous palpomere. Tarsomeres 1-3 with entire sole, tarsomere 3 of all tarsi narrow. Dissection of the abdomen of one female gave 7 large eggs (length $1.8-2.0 \mathrm{~mm}$ ) with thin exochorion and embryo visible through it. Length $7.2-7.8 \mathrm{~mm}$, width $4.8-5.1 \mathrm{~mm}$

DIFFERENTIAL DIAGNOSIS. Short aedeagus with broad anchor-shaped apex (Figs 3-7) immediately distinguishes the new species from all known Nepalese Chrysolina (see Figs 8-9,10-17). Elytra with 9 regular rows of punctures (Figs 19-21) place it closer to Ch. dhaulagirica and $\mathrm{Ch}$. hartmanni. But from both species having red fulvous marginal stripe on elytra and pronotal lateral calli distinct and basally divided from disc with a groove it differs in having colour entirely dark bronze and lateral calli of pronotum not or feebly separated from disc (Figs 19-21). From Ch. nagaja (Fig. 18) and Ch. daccordii having uniformly bronze body and similar habitus it differs in having regular rows of punctures on elytra.

ETYMOLOGY. The species is dedicated to my friend Roman Dudko (Novosibirsk, Russia), who collected the type series.

High mountain Chrysolina with reduced wings from Nepal Himalaya can be determined with the key below.

1 (4) Upperside dull, dark bronze. Elytra covered by dense, moderately large, entirely irregular punctures (Fig. 18).

2(3) Pronotum without lateral calli and impressions. Aedeagus with apex prolonged and anchor-shaped (Figs 8-9). Length: $6.0-6.4 \mathrm{~mm}$ (male), $7.0 \mathrm{~mm}$ (female). Pakistan, Eastern Nepal (Solukhumbu, Sankhuwasabha, Taplejung Distr.) Ch. nagaja (Daccordi, 1982)
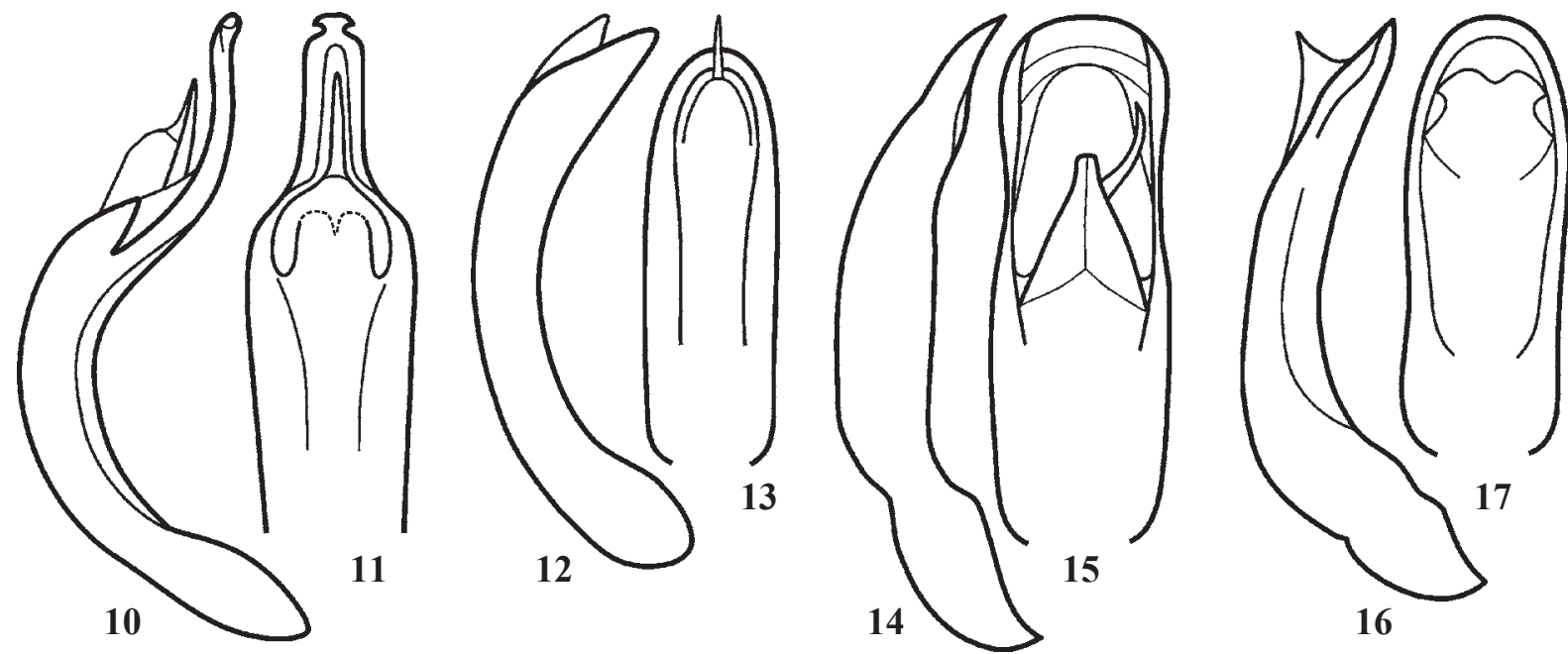

Figs 10-17. Chrysolina, aedeagus: 10-11 - Ch. daccordii (L. Medvedev et Sprecher-Uebersax, 1999); 12-13 - Ch. hartmanni Medvedev, 1999; 14-15 - Ch. dhaulagirica dhaulagirica Medvedev, 1990; 16-17 - Ch. dhaulagirica arunensis Medvedev, 1992; 10, 12, 14, 16 - lateral view; 11, 13, 15, 17 - dorsal view [10-11 - after Bienkowski, 2013; 12-13 - after Medvedev, 1999; 14-15 - after Medvedev, 1990; 16-17 - after Medvedev, 1992, slightly modified].

Рис. 10-17. Chrysolina, эдеагус сбоку и сверху: 10-11 - Ch. daccordii (L. Medvedev et Sprecher-Uebersax, 1999); 12-13 - Ch. hartmanni Medvedev, 1999; 14-15 - Ch. dhaulagirica dhaulagirica Medvedev, 1990; 16-17 - Ch. dhaulagirica arunensis Medvedev, 1992; 10, 12, 14, 16 - сбоку; 11, 13, 15, 17 - сверху [10-11 — по Bienkowski, 2013; 12-13 — по Medvedev, 1999; 14-15 — по Medvedev, 1990; 16-17 - по Medvedev, 1992, с небольшими изменениями]. 


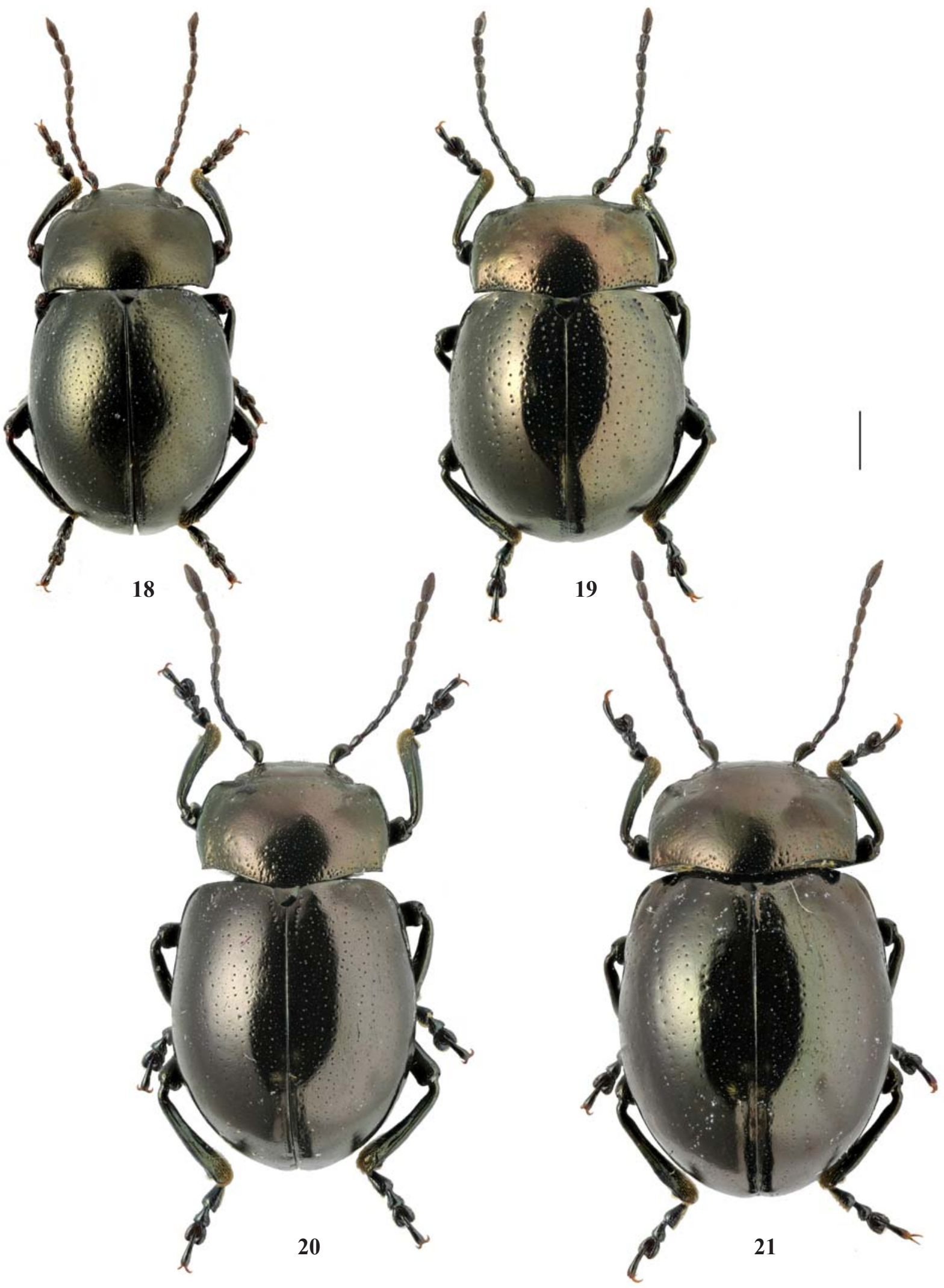

Figs 18-21. Chrysolina, general dorsal view: 18 - Ch. nagaja (Daccordi, 1982) from env. Lamjura La Pass; 19-21 — Ch. romandudkoi sp.n., paratypes (19-20 - males, 21 - female). Scale bar - 1mm.

Рис. 18-21. Chrysolina, общий вид сверху: 18 - Ch. nagaja (Daccordi, 1982) из окрестностей перевала Lamjura La; 19-21 - Ch. romandudkoi sp.n., паратипы (19-20 - самцы, 21 - самка). Масштаб - 1мм. 
3(2) Lateral calli of pronotum distinctly convex, especially basally, where it is delimited with impression. Aedeagus (Figs 10-11) strongly curved in lateral view with long narrow apical projection ending with anchor-like tip. Length: 5.7-6.7 $\mathrm{mm}$ (male), 7.1-7.3 $\mathrm{mm}$ (female). Western Nepal (Mustang and Manang Distr.)

Ch. daccordii (L. Medvedev et Sprecher-Uebersax, 1999)

4 (1) Upperside shining. Elytra with punctures forming 9 slightly irregular paired rows.

5 (12) Punctures in elytral rows rather small and sparse, interspaces flat, shagreened and very finely punctured.

6 (11) Pronotum with lateral calli distinct, divided from disc with a groove in basal third and strong punctures anteriorly. Basal and lateral margins of elytra red fulvous.

7(8) Elytra without humeral calli, puncture rows distinctly paired. 1st tarsomeres of fore tarsi in males strongly dilated. Body dark bronze, elytral lateral stripe occupying two outermost intervals and epipleurae red fulvous, pronotal lateral calli brown. Aedeagus (Figs 12-13) with rounded apex and straight flagellum, placed more apically. Length 7.1-8.0 mm. Mid Western Nepal (Jumla Distr.) Ch. hartmanni Medvedev, 1999

8(7) Elytra with very weak humeral calli. Elytral rows not distinctly paired. 1st tarsomeres in males moderately dilated.

9(10) Larger, elytral punctures in the rows dense. Body dark blue, both basal and lateral red fulvous margins of elytra broad. Aedeagus (Figs 14-15) with spatula shaped apex and flagellum placed more basally. Length: $5.8 \mathrm{~mm}$ (male), 6.0-6.5 mm (female). Western Nepal (Myagdi Distr.).. ....... Ch. dhaulagirica dhaulagirica Medvedev, 1990

10(9) Smaller, elytral punctures in the rows sparse. Body dark bronze, basal red fulvous margins of elytra narrow. Aedeagus (Fig. 16-17) with rounded apex and flagellum placed more apically. Length: $5.2-5.5 \mathrm{~mm}$ (male), $6.0 \mathrm{~mm}$ (female). Eastern Nepal.

Ch. dhaulagirica arunensis Medvedev, 1992

11 (6) Pronotum with obsolete lateral calli, only in females divided from disc with a smooth depression in basal third. Elytra uniformly bronze. Aedeagus (Figs 3-7) apically truncated, with lateral denticles and flagellum straight tubular. Length: 6.0-7.0 (male), 7.2-7.8 mm (female). Eastern Nepal (Bhojpur and Solukhumbu Distr.)

Ch. romandudkoi $\mathbf{s p .} \mathbf{n}$.

12 (5) Punctures in elytral rows rather large, interspaces moderately convex (Figs 1-2). Elytra dark bronze; pronotum greenish, finely granulate, uniformly covered with fine punctures, with a pair of short oblique lateral depressions at basal margin. Females unknown. Length: 9.2-9.5 mm. Eastern Nepal ..... Ch. tangalaensis Kimoto, 2001.

Acknowledgements. I am grateful first of all to my friend Roman Dudko (ISEA, Novosibirsk, Russia), who collected the type series of the new species in Nepal, to Dr. Kirill Makarov (Moscow Pedagogical State University, Russia) for his kind assistance in taking high resolution photos of the beetles from my collection, to Dr. Ako Tachi (Kyushu University, Fukuoka, Japan) and Masakazu Hayashi (Hoshizaki Green foundation, Izumo, Japan) for providing me with the photos of the types preserved in Japan.

\section{References}

Bienkowski A.O. 2013. The members of the subgenus Semenowia Weise, 1889 of the genus Chrysolina Motschulsky, 1860 (Coleoptera: Chrysomelidae)//Caucasian Entomological Bull. Vol.9. No.1. P. 97-101.

Daccordi M. 1982. Crisomeline orientali nuove o poco note del Museo di Storia Naturale di Basilea (Svizzera) (Col. Chrysomelidae) // Entomologica Basiliensia. Vol.7. P.394-405.

Daccordi M. 1994. Notes for phylogenetic study of Chrysomelinae, with descriptions of new taxa and a list of all the known genera (Coleoptera: Chrysomelidae, Chrysomelinae) // Proceedings of the 3rd International Symposium on the Chrysomelidae, Beijing, 1992. Leiden: Backhuys Publ. P.60-84.

Ge S.-Q., Daccordi M., Beutel R.G., Ren J., Cui J.-Z., Li W.-Z., Yang X.-K. 2012. Revision of the Eastern Asian genera Ambrostoma Motschulsky and Parambrostoma Chen (Coleoptera: Chrysomelidae: Chrysomelinae) // Systematic Entomology. Vol.37. P.332-345.

Halberg K. 2017. Plant geography and vegetation zones of the Himalaya. URL: http://kajhalberg.dk/en/plants/plant-huntingin-the-himalaya/plant-geography-and-vegetation-zones-of-thehimalaya/

Hartmann M., Medvedev L.N. 2003. To the knowledge of Nepalese Chrysomelidae (Coleoptera) // Veröffentlichungen Naturkundemuseum Erfurt. Vol.22. P.153-183.

Kimoto S. 2005. Systematic Catalog of the Chrysomelidae (Coleoptera) from Nepal and Bhutan // Bull. Kitakyushu Mus. Nat. Hist. Hum. Hist. Ser.A. No.3. P.13-114.

Kippenberg H. 2010. Chrysomelinae // Catalogue of Palaearctic Coleoptera. Vol.6. Stenstrup: Apollo Books. P.390-443.

Mani M.S. 1968. Ecology and biogeography of high altitude insects. The Hague: Junk Publ. 527 pp.

Medvedev L.N. 1990. Chrysomelidae from the Nepal Himalayas, II (Insecta, Coleoptera) // Stuttgarter Beiträge zur Naturkunde. Ser.A (Biologie). No.453. P.1-46.

Medvedev L.N. 1992. Chrysomelidae from the Nepal Himalayas, III (Insecta, Coleoptera) // Stuttgarter Beiträge zur Naturkunde. Ser.A (Biologie). No.458. P.1-36.

Medvedev L.N. 1999. To the knowledge of Chrysomelidae (Coleoptera) from Nepal and adjacent regions // Veröffentlichungen Naturkundemuseum Erfurt. Vol.18. P.181-187.

Medvedev L.N., Sprecher-Uebersax E. 1999a. Katalog der Chrysomelidae von Nepal // Entomologica Basiliensia. Vol.21. P.261-354.

Medvedev L.N., Sprecher-Uebersax E. 1999b. Taxonomical study of Chrysomelidae (Coleoptera) from Nepal // Entomologica Basiliensia. Vol.21. P.355-370.

Medvedev L.N., Sprecher-Uebersax E. 2005. A key to the leaf beetle genera of Nepal (Coleoptera, Chrysomelidae) // Entomologica Basiliensia et Collectionis Frey. Vol.27. P.375-512.

Sprecher-Uebersax E. 2011. A new catalogue of leaf beetles (Coleoptera, Chrysomelidae) from Nepal // Entomologica Basiliensia et Collectionis Frey. Vol.33. P.375-512. 